\title{
PENGARUH MEDIA PEMBELAJARAN DAN MOTIVASI TERHADAP PRESTASI BELAJAR SIMULASI DIGITAL (Studi Quasi Eksperimen Pada Siswa Kelas X Usaha Perjalanan Wisata SMK N 1 Kota Bengkulu)
}

\author{
Isti Herlena \\ Guru SMKN 1 Kota Bengkulu \\ Email: istiherlena@yahoo.co.id
}

\begin{abstract}
The study was aimed to investigation the influence of the teaching media and motivation toward the learning achievement of Digital Simulation of X Tecnologi Information Comunication grade students of the 2017/2018 Academic Year, at State Vocational School 1 Bengkulu City. The experiment quasi study, purposive randome sampling in which 68 studen as its sample were taken as well, and two variance analysis. (Anava) technique with significance level $\mathrm{P}<0,05$, were employed. The following research result, with the significance level $\mathrm{P}<0,05$, were revealedthat there were ; (1) influence of the use of the computer media and LCD projector with Power Point program toward the students' motivation, with $\mathrm{F}=4,822$, and the students'achievement, with $\mathrm{F}=1,752$, in learning the Computer Skills and Information management; (2) Interaction between prior to and afterwards treatment givent to the experiment and control group towards the students' motivation, with $\mathrm{F}=4,822$; and (3) no interaction between prior to and afterwards treatment given to the ekperiment and control group toward the students' achievement, with $\mathrm{F}$ $=1,752$.
\end{abstract}

Keywords: Media, Motivation, Achievement

Abstrak: Penelitian ini bertujuan untuk mengetahui pengaruh media pembelajaran dan motivasi terhadap prestasi belajar Simulasi Digital siswa kelas X Usaha Perjalan Wisata tahun ajaran 2017/2018. Penelitian ini menggunakan metode quasi eksperimen. Purposive random sampling yang mana 68 siswa diambil sebagai sampel. Teknik analisis yang digunakan adalah analisis Varians (Anava) dua jalur campuran pada taraf signifikansi $\mathrm{p}<0,05$. Hasil penelitian menunjukkan; (1) Terdapat pengaruh penggunaan media komputer dan LCD proyektor menggunakan program Power Point terhadap motivasi belajar Simulasi Digital siswa dengan perhitungan $\mathrm{F}=4,822$ dan prestasi belajar siswa, dengan perhitungan $\mathrm{F}=1,752$ (2) Terdapat interaksi antara sebelum perlakuan dengan setelah perlakuan dari kelompok ekperimen dan kontrol terhadap motivasi belajar siswa dengan perhitungan $\mathrm{F}=4,822$; (3) Tidak terdapat interaksi antara sebelum perlakuan dengan setelah perlakuan dari kelompok ekperimem dan kontrol terhadap prestasi belajar siswa dengan perhitungan $\mathrm{F}=1,752$.

Kata Kunci: Media, Motivasi, Prestasi.

\section{PENDAHULUAN}

Pesatnya perkembangan ilmu pengetahuan dan teknologi menuntut pula peningkatan kualitas pendidikan untuk mengimbanginya, sehingga akan menghasilkan sumber daya yang berkualitas dan siap bersaing dengan bangsa-bangsa lain.

Simulasi Digital merupakan mata pelajaran C1 Dasar Bidang Keahlian yang ada di kurikulum SMKN 1 kota Bengkulu. Mata pelajaran ini bersifat praktik. Pada waktu akan memulai pelajaran Simulasi Digital di Laboratorium komputer atau di kelas, guru kesulitan menjelaskan materi-materi yang banyak gambarnya, seperti menjelaskan menu-menu utama Peta Minda, Microsof Word, MS. Powerpoint, maka sangat diperlukan LCD Proyektor dan Komputer untuk menampilkan gambar dan menu-menu yang bervariasi. Tulisan atau gambar tersebut dapat dibuat animasi dengan menggunakan program Power Point yang dapat memperlihatkan seolah-olah nyata dapat memotivasi siswa sehingga mereka merasa senang untuk belajar Simulasi DIgital. Oleh karena itu, perlu upaya untuk mengatasi permasalahan tersebut sehingga penguasaan konsep Simulasi Digital lebih optimal dan siswa juga selalu merasa senang belajar Simulasi Digital. Salah satu metode yang dapat menarik adalah pembelajaran dengan menggunakan media pembelajaran Lequit Cristal Display (LCD) Proyektor dan Komputer.

Menurut Sisilain (2010:11) Lequit Cristal Display (LCD) Proyektor merupakan perangkat optik untuk memperoyeksikan sinar cahaya, instrument optik yang proyek gambar di perbesar kedalam sebuah layar. Media berbasis komputer dapat diartikan sebagai teknologi yang mengoptimalkan peran komputer sebagai sarana untuk menampilkan dan merekayasa teks, grafik, dan suara dalam sebuah tampilan yang terintegrasi. Dengan tampilan yang dapat mengkombinasikan berbagai unsur penyampaian informasi dan pesan, komputer dapat dirancang dan digunakan sebagai media teknologi yang efektif untuk mempelajari dan mengajarkan materi pembelajaran yang relevan misalnya rancangan grafis dan animasi (Sudrajat, 2010:16)

Sekolah Menengah Kejuruan (SMK) Negeri 1 Kota Bengkulu adalah sebuah sekolah kejuruan yang pertama kali di Bengkulu. Sekolah ini terletak di jalan Jati Nomor 41 Sawah Lebar Bengkulu yang mempunyai 6 Kompetensi keahlian yaitu Akuntansi, Pemasaran, Administrasi perkantoran, Usaha Perjalanan Wisata, Multimedia, 
Teknik Komputer \& Jaringan. Di sekolah inilah penulis mengajar. Jumlah siswanya mencapai 1.300 orang pada tahun 2017/2018. Di sekolah ini peralatan media pembelajaran yang berbasis Komputer masih sangat kurang. Belum semua jurusan mempunya komputer dan lab sendiri. Hal ini disebabkan karena ruangan terbatas dan kemampuan keuangan sekolah juga terbatas. Kompetensi keahlian yang belum mempunyai lab sendiri adalah kompetensi keahlian Pemasaran dan kompetensi keahlian Usaha Perjalanan Wisata (UPW). Untuk belajar komputer kedua kompetensi ini masih menggunakan lab komputer kompetensi keahlian Multimedia. Mereka baru bisa pakai lab kalau labnya tidak dipakai oleh kompetensi keahlian Multimedia. Satu lab komputer terdiri dari 20 unit sedangkan siswa yang belajar satu kelas ada 34 orang.

Jumlah LCD juga hanya 20 unit sedangkan guru yang mengajar berjumlah 100 orang dengan 32 kelas. Jadi untuk memakai media pembelajaran yang berupa LCD dan Laptop/Komputer harus bergantian. Jika LCD dipakai sama guru yang lainnya otomatis kita mengajar menggunakan media konvensional yaitu media non elektronik seperti menggunakan Modul dan LKS. Disamping itu kemampuan guru dalam menggunakan media pembelajaran yang berupa laptop dan LCD dengan menggunakan program Power Point atau kamajuan teknologi lainnya masih kurang.

Media pembelajaran Komputer Dan LCD proyektor sangat tepat digunakan dalam mata pelajaran Simulasi Digital karena dengan media ini motivasi siswa untuk belajar meningkat dan prestasinya juga meningkat. Pembelajaran dengan media konvensional (Modul dan LKS) kurang menarik bagi siswa sehingga motivasi belajar siswa rendah dan prestasi belajarnya juga rendah. Disamping itu kemauan siswa untuk belajar juga rendah. Siswa lebih suka main Handpon, Face Book ataupun game. Dengan memerhatikan paragraf di atas, maka penulis tertarik untuk melakukan penelitian dengan judul " Pengaruh media pembelajaran dan motivasi terhadap prestasi belajar Simulasi Digital. Studi ekperimen pada siswa kelas X Usaha Perjalanan Wisata SMK Negeri 1 Kota Bengkulu".

\section{METODE}

Penelitian dilaksanakan di SMK Negeri 1 Kota Bengkulu. Kegiatan penelitian ini melibatkan tiga kompetensi keahlian yaitu kompetensi keahlian Usaha perjalanan Wisata (UPW) sebagai kelas ekperimen, kompetensi keahlian Pemasaran sebagai kelas kontrol dan kompetensi keahlian Multimedia sebagai kelas uji coba. Di sekolah inilah penulis bertugas sebagai guru mata pelajaran Simulasi Digital.

Kegiatan penelitian dilaksanakan lebih kurang 3 bulan yaitu bulan Pebruari 2018 digunakan untuk observasi, uji coba instrumen dan Free test sedangkan bulan Maret dan April 2018 digunakan untuk pelaksanaan ekperimen, post test serta pengukuran motivasi dan prestasi belajar Simulasi Digital.

Penelitian ini menggunakan metode quasi eksperimen. Dengan menggunakan teknik analisis varian (ANOVA Mix) 2 jalur campuran. Populasi pada penelitian ini adalah semua siswa kelas X SMK Negeri 1 kota Bengkulu yang mengikuti pelajaran Simulasi Digital. Sampel penelitian ini adalah siswa kelas X semester 2 tahun pelajaran 2017/2018. Pengambilan sampel tidak dilakukan secara acak untuk kompetensi keahlian Usaha Perjalanan Wisata karena hanya ada 1 kelas tetapi untuk kompetensi Pemasaran pengambilan sampel dilakukan secara acak karena ada 2 kelas.. Dari kedua kelas tersebut kelas X Usaha Perjalanan Wisata (UPW) dijadikan kelas ekprimen (pemanfaatan komputer sebagai media pembelajaran dengan jumlah siswa 34 orang yang terdiri dari 12 orang laki-laki, 22 orang perempuan), dan kelas X Pemasaran 2 sebagai kelas kontrol (pembelajaran dengan media konvensional dengan jumlah siswa 34 orang yang terdiri dari 14 orang laki-laki, 20 orang perempuan). Sampel ini dipilih berdasarkan pertimbangan bahwa pada semester 2 dan periode tersebut dimungkinkan untuk penggunaan media pembelajaran dimaksud.

Penelitian ini menggunakan dua jenis instrumen yaitu angket dan tes prestasi. a. Angket.

Angket adalah daftar pertanyaan yang diberikan kepada orang lain yang bersedia memberikan respons sesuai dengan permintaan pengguna (Ridwan, 2007:25). Tujuan penyebaran angket ialah mencari informasi yang lengkap mengenai sesuatu masalah dari responden tanpa merasa khawatir tentang akibat jawaban yang sesuai dengan keadaan sebenarnya.

Menurut Sudjana dan Ibrahim (2001:105) menyatakan bahwa skala adalah untuk mengukur nilai, sikap, minat, perhatian, motivasi yang disusun dalam bentuk pernyataan untuk dinilai dan hasilnya berupa rentangan nilai angka sesuai dengan kriteria yang dibuat peneliti. Angket dalam penelitian ini dipakai untuk mendapatkan data motivasi dengan pengukuran menggunakan skala Likert. Skala ini disusun dalam bentuk suatu pertanyaan dan diikuti oleh lima respons yang menunjukkan tingkatan. Selanjutnya pernyataan-pernyataan tersebut dilakukan uji coba kepada siswa kelas X kompetensi keahlian Multimedia SMK N 1 Kota Bengkulu. Hasil uji coba kemudian dianalisis validitas dan reliabilitasnya. Validitas menyatakan index item total correlation antara 0,268 sampai dengan 0,571. Sedangkan reliabilitas instumen motivasi pada penelitian ini menggunakan Alpha Cronbach's sebesar 0,819. Hal ini menunjukkan bahwa instrumen motivasi belajar dalam kategori reliabel/andal. 


\section{HASIL PENELITIAN DAN PEMBAHASAN}

\section{Hasil Penelitian}

Pada bagian ini disajikan hasil perhitungan data meliputi; rata-rata (mean), median, standard deviasi, max, min, variance, range dalam bentuk deskripsi data penelitiani seperti terlihat pada berikut ini:

Tabel 1. Deskripsi Data Penelitian

\begin{tabular}{|c|l|r|r|r|r|r|r|r|}
\hline & Kelompok & \multicolumn{1}{l|}{ Mean } & \multicolumn{1}{l|}{ Median } & \multicolumn{1}{l|}{ Std } & Max & \multicolumn{1}{l|}{ Min } & Range & N \\
\hline \multirow{2}{*}{ Premotivasi } & Ekperimen & 94,97 & 94,50 & 12,26 & 119 & 70 & 49 & 34 \\
\cline { 2 - 9 } & Kontrol & 88,32 & 86,50 & 9,82 & 108 & 69 & 39 & 34 \\
\hline \multirow{2}{*}{ Preprestasi } & Ekperimen & 67,68 & 68 & 8,59 & 83 & 53 & 40 & 34 \\
\cline { 2 - 9 } & Kontrol & 54,68 & 55 & 11,09 & 75 & 30 & 45 & 34 \\
\hline Posmotivasi & Ekperimen & 109,12 & 110 & 3,74 & 117 & 102 & 15 & 34 \\
\hline & Kontrol & 96,88 & 97,50 & 5,88 & 107 & 80 & 27 & 34 \\
\hline \multirow{2}{*}{ Posprestasi } & Ekperimen & 81,18 & 80 & 5,45 & 93 & 70 & 23 & 34 \\
\cline { 2 - 9 } & Kontrol & 70,62 & 70 & 5,05 & 80 & 63 & 17 & 34 \\
\hline
\end{tabular}

Pengujian persyaratan analisis dilakukan terhadap uji normalitas dan uji homogenitas yang bertujuan untuk membantu hasil analisis agar lebih mendekati kepada hasil yang lebih baik.

Berdasarkan hasil perhitungan uji normalitas dengan teknik Kolmogorov Smirnov signifikansi untuk setiap kelompok adalah sebagai berikut : (1) Motivasi belajar siswa sebelum perlakuan pada kelompok ekperimen (kelompok siswa yang menggunakan media pembelajaran Komputer dan LCD proyektor) signifikansi normalitas sebesar 0,108 , (2) Motivasi belajar siswa sebelum perlakuan pada kelompok kontrol (kelompok siswa yang menggunakan media konvensional atau modul dan LKS) signifikansi normalitas sebesar 0,200, (3) Prestasi belajar siswa sebelum perlakuan pada kelompok ekperimen (kelompok siswa yang menggunakan media pembelajaran Komputer dan LCD proyektor) signifikansi normalitas sebesar 0,012, (4) Prestasi belajar siswa setelah perlakuan pada kelompok kontrol (kelompok yang menggunakan media konvensional atau modul dan LKS) signifikansi normalitas sebesar 0,200, (5) Motivasi belajar siswa setelah perlakuan pada kelompok ekperimen (kelompok siswa yang menggunakan media pembelajaran Komputer dan LCD proyektor) signifikansi normalitas sebesar 0,021, (6) Motivasi belajar siswa setelah perlakuan pada kelompok kontrol (kelompok yang menggunakan media konvensional atau modul dan LKS) signifikansi normalitas sebesar 0,192, (7) Prestasi belajar siswa setelah perlakuan pada kelompok ekperimen (kelompok siswa yang menggunakan media pembelajaran Komputer dan LCD proyektor) signifikansi normalitas sebesar 0,001, (8) Prestasi belajar siswa setelah perlakuan pada kelompok kontrol (kelompok siswa yang menggunakan media konvensional atau modul dan LKS) signifikansi normalitas sebesar 0,002.

Berdasarkan Perhitungan uji homogenitas dengan teknik One-Sample Kolmogorov -Smirnov Test premotivasi nilai signifikansinya sebesar 0,960 ini menunjukkan bahwa $\mathrm{p}>0,05$ yang artinya data homogen. Begitu juga dengan kelompok preprestasi signifikansinya sebesar 0,262 ini menunjukkan bahwa $\mathrm{p}>0,05$ yang artinya data homogen. Untuk kelompok posmotivasi nilai signifikansinya sebesar 0,325 ini menunjukkan bahwa $p>0,05$ yang artinya data homogen. Kelompok posprestasi nilai signifikansinya sebesar 0,146 ini menunjukkan bahwa $p>0,05$ yang artinya data homogen.

\section{Pembahasan}

Hasil pengujian hipotesis pertama menunjukkan $\mathrm{H}_{0}$ ditolak dan $\mathrm{H}_{\mathrm{a}}$ diterima artinya ada pengaruh penggunaan media pembelajaran terhadap motivasi belajar siswa

Hasil pengujian hipotesis kedua menunjukkan $\mathrm{H}_{0}$ ditolak dan $\mathrm{H}_{\mathrm{a}}$ diterima artinya, ada pengaruh penggunaan media pembelajaran terhadap prestasii belajar siswa.

Hasil pengujian hipotesis ketiga menunjukkan $\mathrm{H}_{0}$ ditolak dan $\mathrm{H}_{\mathrm{a}}$ diterima artinya, ada interaksi antara penggunaan media pembelajaran terhadap motivasi belajar siswa.

Hasil pengujian hipotesis keempat menunjukkan $\mathrm{H}_{0}$ diterima dan $\mathrm{H}_{\mathrm{a}}$ ditolak artinya, tidak ada interaksi antara penggunaan media pembelajaran terhadap prestasi belajar siswa

\section{SIMPULAN}

Berdasarkan pengaruh penggunaan media dan motivasi terhadap prestasi:

1. Terdapat pengaruh penggunaan media komputer dan LCD proyektor menggunakan program Power Point terhadap motivasi belajar Simulasi Digital siswa.

2. Terdapat pengaruh penggunaan media komputer dan LCD proyektor menggunakan program Power Point terhadap prestasi belajar Simulasi Digital siswa.

3. Terdapat interaksi antara sebelum perlakuan dengan setelah perlakuan dari kelompok 
ekperimen dan kontrol terhadap motivasi belajar siswa.

4. Tidak terdapat interaksi antara sebelum perlakuan dengan setelah perlakuan dari kelompok ekperimen dan kontrol terhadap prestasi belajar siswa.

\section{DAFTAR PUSTAKA}

Arasyad, 2010. Media pembelajaran Raja Grafindo Persada. Jakarta

Arikunto, Suharsimi. 2006. Prosedur penelitian suatu pendekatan praktek. Jakarta: Rinika Cipta

Akhmad Sudrajat, 2010, Pengertian Media Pembelajaran diunduh dari: http://akhmadsudrajat.wordpress.com/2010/07/ 16/media-pembelajaran-berbasis-komputer, pada tanggal 15 Mei 2012

Brigggs, Sadiman, 2007 Media Pembelajaran. Bandung, CV Wacana Prima

Dahlan, 1984. Model-model mengajar ( Beberapa Alternatif interaksi belajar mengajar) cv. Diponegoro Bandung.

Gagne, Sadiman, 2007. Media Pembelajaran Raja Grafindo Persada. Jakarta

Hadiwinarto, 2009. Psikologi (Teori dan Pengukuran) Bengkulu.

Hamalik, O. 1994. Media Pendidikan, cetakan ke-7. Bandung: PT. Citra Aditya Bakti.
Hamzah, 2007. Model Pembelajaran menciptakan proses belajar mengajar yang kriatif dan efektif. Bumi Aksara. Jakarta

Johanes Sapri,2006. Pengaruh Model Pembelajaran dan gaya

Kognitif terhadap hasil belajar

Rosada (2008: 7) Media Pembelajaran, Bandung, CV Wacana Prima

Sanaky, Huajair AH. 2009. Media Pembelajaran, edisi Revisi. Yogyakarta: Safira insania Press

Sanjaya, Wina. 2008. Strategi Pembelajaran. Jakarta : Kencana Prenada Media Gruop.

Setiawan, Denny dkk. 2008. Komputer Dan Media Pembelajaran. Jakarta, Universitas Terbuka

Sisilian. 2010, Pengertian LCD Proyektor. diunduh dari:

Http://www.sisilain.net/2010/11/pengertian-lcdproyektor.html, pada tanggal 15 Mei 2012

Slavin, 2009. Psikologi Pendidikan. Jakarta, Erlangga

Soeryono Soekamto, 1980, Pengantar Sosiologi, Jakarta, Balai Pustaka

Sugiono, 2010. Metode penelitian Pendidikan (pendekatan kuantitatif, kualitataif dan R\&. Afabeta. Bandung

Pandapotan Sianipar, 2004, Menggunakan Microsoft Office Power Point 2003, Jakarta, Elex Media Komputindo

Sudrajat dkk, 2000. Statistik pendidikan. Bandung Pustaka Setia. 